DOI: 10.46340/ephd.2021.7.4.10

\author{
Zhan Na \\ ORCID ID: https://orcid.org/0000-0003-4791-5913 \\ National Technical University of Ukraine \\ "Igor Sikorsky Kyiv Polytechnic Institute"
}

\title{
ETHICAL ANALYSIS OF THE SOCIAL STATUS OF WOMEN IN CONTEMPORARY CHINA
}

After the founding of the people's Republic of China, politically, China promulgated a series of laws to protect women's political participation. These continuously improved policies and laws have made women's political participation legal. While women fulfill their obligations, they should be given more rights. It is gratifying that women's awareness and ability to participate in politics have also been improved, and more and more able women appear in the public view; In the family, through the investigation of the social status of Chinese women in the second period, the data show that $40 \%$ of husbands have more real power in the family, about $40 \%$ of cou ples have equal rights and responsibilities in the family, and $20 \%$ of wives have more real power. In other words, $60 \%$ of wives share real power. In the long run, the number of women sharing real power in the family will only increase. In terms of employment, women's employment opportunities, scope of employment and number of employment are moving closer to men. However, the influence of traditional ethics is far-reaching. Women are not allowed to participate in politics, which makes them lack of initiative in striving for rights. Under the influence of traditional ideas such as men in charge of the outside, women in charge of the inside, good wives and good mothers, over time, women have become men's economic dependence, and then become personal dependence. The idea of son preference affects women's education. In addition, the spread of modern hedonism and money worship leads to changes in women's economic, marriage and learning concepts, which makes Chinese women, At least some Chinese women leave the impression of money worship women, secular and superficial, which seriously affects the improvement of women's social status.

Keywords: Ethical analysis, Gender equality, Female participation in politics, Female employment, Female education.

\section{Introduction}

Looking back at the history of China, the social status of women can be roughly divided into three stages: the first stage - the matriarchal period of primitive society, where women are relatively respected by men; the second stage - traditional society (middle-late primitive society, slave society and feudal society), male superiority, women are vassals of men; third stage, modern civilized society, men and women strive for equality. The May Fourth Movement in China in 1919 allowed women to truly awaken. The activities that banned women from entering educational institutions were canceled, the number of girls' schools gradually increased and women were freed. Since the founding of the PRC, the position of women in politics, family and employment has improved significantly. Politically, China has passed a number of laws to protect the participation of women in politics. These ever-improving policies and laws have made it legal for women to participate in politics. By fulfilling their responsibilities, women are given more rights. What is encouraging is that women's awareness and ability to participate in politics has also increased, and more and more powerful women are appearing in the public eye. As for the family, the data obtained in the second stage of the study of the social status of Chinese women show that $40 \%$ of husbands have more real power in the family, about $40 \%$ of couples have equal rights and responsibilities in the family, and $20 \%$ of wives have more power. In other words, $60 \%$ of wives share real power in the family $(71 \%$ in cities and $56 \%$ in rural areas) $)^{1}$. This was not possible before the founding of the PRC. This data also changes. In the long term,

\footnotetext{
${ }^{1}$ National Bureau of Statistics (2021). Main data report of the second sampling survey on the social status of Chinese women .<http://www.stats.gov.cn/tjsj/tjgb/qttjgb/qgqttjgb/200203/t20020331_30606.html> (2021, November, 12).
} 
the number of women who share real power in the family will only increase. In terms of employment, with the development of China's economy, politics and culture, the position of women in employment has improved significantly. The employment opportunities for women, the scale of employment and the number of jobs are all moving closer to men.

Huang $\mathrm{Jie}^{1}$ starts with biological factors and analyzes the physical and psychological differences between men and women; Then with social factors in order to analyze the influence of the history, economy, politics and culture of China on the formation of gender status differences and understanding the reasons for the formation of status differences between men and women in China. Yang Yiying ${ }^{2}$ examines women's entrepreneurial intentions as an object of research and examines the influence of four influencing factors: gender role, personal characteristics, entrepreneurial environment and interpersonal connections on women's entrepreneurial intentions. Zhang Xia and $\mathrm{Ru} \mathrm{Xue}^{3}$ analyzed the impact of productivity, systems, ideas and culture on women's economic status in terms of historical change. They believe that the key to improving the economic status of Chinese women is to eliminate gender differences in productivity and then related social and value systems. Li Guimei and Ouyang Zhuolin ${ }^{4}$ examined the general state of family virtues, professional ethics, social ethics, and female morality in contemporary Chinese women from an ethical point of view. Research shows that the moral status of Chinese women is generally good.

However, discrimination against women still exists in society. This article analyzes the reasons for this phenomenon:

1. Chinese and Western ideological factors

1.1 The Deep Influence of Traditional Ethics

In the traditional Chinese system of ideas about gender roles, patriarchy has always been at the center of attention. The patriarchal ruling culture under patriarchy determines the subordinate status of women. Women have no independent personality and dignity, no self-awareness, and it is impossible to create their own value system. The image of a woman is not simply determined from birth, but is more developed in accordance with the needs and standards of men under patriarchal rule. They formulate ethical norms for women running in the whole society, and require women's development from the subconscious, acquired education, social moral requirements and legal provisions. In fact, these traditional feudal dogmas are tools that restrict women's development in a patriarchal society. They not only destroy women's physical development, but also psychologically destroy women's awakening of self-consciousness, deprive women of their human rights, and limit the development of women's overall quality, what is more serious is that women's expectations and requirements for success in society are also diluted and ignored. In order to consolidate the rule of men's power, they have always advocated that women should obey the laws of heaven (Ancient Chinese philosophy terms. Materialism believes that the laws of the heaven are an objective law of nature, its development and change. Idealism believes that the laws of heaven are an expression of the will of God and a sign of good luck and bad luck.) be tender like water, strong men and weak women, which are the shackles of traditional culture accumulated in women's ideology over a long period of time and have a far-reaching impact on their real life.

1.1.1 Women shall not participate in politics

Although women in modern China are more concerned about public affairs and their ability to participate in politics is higher than before, the degree of women's direct participation in decisionmaking is still not high. Women are not allowed to participate in politics, "there is no woman above the court", women do not have the right to speak for themselves, and the influence of traditional ideas still exists, which makes Chinese women not invest enough energy in participating in and discussing politics, have not enough enthusiasm for participating in and discussing politics, and it is more difficult for women to take the road of participating in and discussing politics than men. The tendency of masculinity is still obvious in public decision-making. In China's history, women have been excluded from the political power for a long time and have no opportunity to participate in the political power, which makes them lack of initiative in striving for rights.

\footnotetext{
1 黄洁 (2020).我国男女两性的差异性分析. 三峡大学学报 (人文社会科学版), S1,10-14.

2 杨易莹 (2018). 女性创业意向及其影响因素实证研究(硕士学位论文,西南交通大学

$<$ https://kns.cnki.net/KCMS/detail/detail.aspx?dbname=CMFD201802\&filename=1018977032.nh > (2021, November, 12).

3 张霞 \& 茹雪 (2017). 中国女性经济地位的历史演进及其当代启示. 福建论坛 人文社会科学版), 09, 166-173.

4 李桂梅 \& 欧阳卓灵 (2015). 当代中国女性道德状况调查. 伦理学研究, 04, 17-26.
} 
1.1.2 Male is in charge of external affairs and female is in charge of internal affairs

Women are an important driving force for economic construction and social civilization. In terms of human attributes, they should have the same independent economic ability and competitiveness as men, and should enjoy the same employment opportunities and equal pay for equal work as men. With the rapid development of China's economy, women can be seen everywhere, whether it be in the service industry or in the high-tech industry, whether it is mental labor or manual labor, women's participation is very high. However, due to the long-term influence of the idea of "men in charge of the outside, women in charge of the inside" 1 , it seems natural for men to work outside to support their families, women to teach their husband and children at home, and good internal help as husbands. Therefore, in the process of women's employment, on the one hand, women lack enough entrepreneurial courage and can only rely on policies or other means to promote employment. On the other hand, employers are also influenced by traditional ideas. Many still can not treat female workers fairly and do not give fair competition opportunities. The internal and external division of labor between men and women seems very natural. In fact, over time, women have become men's economic dependence, and then become personal dependence.

1.1.3 Valuing men and despising women

In the traditional thought, the requirements for women are more moral and do not advocate women's education. "A mediocre woman is virtuous. ${ }^{2 "}$ In addition, due to the influence of patriarchal ideology in feudal society, women are not allowed to attend private schools. Only a small number of girls from a noble family or a literary family can touch books, so the general level of education of women is quite low. Until now, compulsory nine-year education has been popularized in large rural areas, but parents still pay more attention to sons than daughters. They don't want to coach their daughters. Women come to school late or drop out to help when they are busy working on the farm. Some female students work hard and finally go to college. They also give up the opportunity to continue their studies because of their brother.

1.1.4 A virtuous wife and loving mother

Influenced by traditional cultural education, the idea of "breadwinning men and homemaking women " continues to influence women's choice and social role-playing. Traditional ethical standards require a woman to play the role of a virtuous spouse and loving mother in a family, when a woman is not married she must live for a father; when she gets married, she must live for her husband; Once she is widowed, she must live for the sake of her children and serve family members instead of actively engaging in social production activities. This kind of thought makes modern Chinese women not have enough confidence and courage in the face of the opportunity to freely explore their career. When facing the choice of career, love and marriage, most women will still choose love and marriage. Traditional gender culture is one of the main means of social formation. Traditional Chinese gender culture, such as the "three obediences and the four virtues ${ }^{3 "}$ (three obediences: in ancient China a woman was required to obey her father before marriage, and her husband during married life and her sons in widowhood and four virtues: fidelity, physical charm, propriety in speech and efficiency in needle work), "three cardinal principles and five permanent principles ${ }^{4 n}$ (three cardinal principles: the absolute power of the sovereign over the subject, the father over the son, the husband over the wife - the ethical norms of old China; five constant principles: philanthropy and justice, ritual, knowledge, and loyalty) ignores women's own potential and deprives them of the right to achieve the realization of social values.

Looking at the impact of traditional ethics on women, we can see that women's rights are vetoed by the power of a patriarchal society. The rule of a patriarchal society is deeply rooted in China and has farreaching influence. She penetrates deeply into social ideology and influences the development of Chinese women and the improvement of their social status.

1.2 Spread of hedonism and money worship

Everyone knows what happiness is, and only a person himself can judge whether he is happy or suffering. Jeremy Bentham believes that "pursuing happiness and avoiding suffering" is an inevitable human tendency. This constitutes his principle of self-interest choice and the principle of happiness maximization based on self-interest choice. The maximization of happiness is also the judgment standard of good and evil

\footnotetext{
1 张建平 (2010). 中国 “男主外, 女主内” 的刻板印象探析 - - 基于社会性别视角. 法制与社会, 17 (200), 1009-0592.

2 李海燕 (2008). 《中国女子教育史》。图书馆杂志, 27 (2), 89-91.

3 杨维中 (2001). 论 “三从四德”的伦理学内涵及其历史局限性. 华夏文化, 2.

4 魏敏, \& 彭丹琴 (2014). 浅析朱喜的 “三纲五常”思想. 法制与社会, 6.

5 钟小燕 (2014). 试论边沁功利主义的当代政治伦理价值. 中共四川省委党校学报, 3, 49-52.
} 
morality. The behavior that can bring happiness to people is good and moral. On the contrary, it is evil and immoral. Since foreign western thoughts have penetrated into China's national consciousness with China's economic and social development, Western utilitarianism, money worship and hedonism have the soil for breeding and development in the process of establishing and perfecting China's market economic system. The period of rapid economic development is also a period of great changes and collisions in people's ideology. In recent years, Chinese people's enthusiasm for money has increased significantly compared with the past, which also leads to changes in women's economic, marriage and learning concepts, which is easy to lead to ideological corruption. In traditional marriages, the standard for choosing a spouse is attention to the status of the family and the same social status and origin. All this is done by the parents and the matchmaker. The attitude of women is not that important. However, nowadays women are free to choose their spouses, the lifestyle they want, they can choose to be a strong woman, a housewife, or both. With socioeconomic development, women are no longer invisible girls who stay at home. More realistic factors make them more and more aware of the gap between reality and dreams.

1.2.1 Hedonism and money worship erode women's self-esteem

Without traditional shackles, women can choose a free and open lifestyle that requires material as a basis. People are no longer satisfied with basic necessities of life such as food, clothing, shelter and transportation. More and more people value quality of life and lead a luxurious life. Such changes have led to the fact that Chinese women, at least a certain part of Chinese women, have lost the traditional wise and virtuous image in the hearts of people, leaving a secular and superficial impression of worshiping money. Because of great material desires, many women lose themselves. They can pay bribes, do erotic deals to get a good job and a life.

1.2.2 Hedonism and money worship affect women's marriage choice

With the development of society, the concept of marriage and love is becoming more and more free. The economic foundation has increasingly become an important factor for both marriage and love. The position of money in people's mind and social life is becoming more and more important. Women's choice of love, not only put aside the marriage restrictions of "parents' orders and matchmakers' words ${ }^{1 "}$ under the constraints of traditional morality, but also pay more pragmatic attention to each other's material conditions, occupation and background. Money worship is on the rise, and some women fall into the misunderstanding of marriage and love. From the perspective of people's own development, money worship is not in line with people's all-round development and sometimes hinders it. A woman's value choice in the concept of marriage and love primarily reflects an improvement in women's independence and autonomy. This deserves recognition, but it is more important to see that the mistress "Little San (mistress)" was rejected and shameless from the very beginning, and now very many women prefer not to have morality, but only material pleasures. This is not only a unilateral reason for women, but also a distortion of social values, which is caused by the pressure of modern life, the lack of social supervision Moral dereliction of duty in media communication and women's limited level of education.

Simone Beauvoir said: "attachment is the misfortune that weighs on most women. No matter whether she can't bear it or take it easy, or even enjoy herself, it is ultimately the misfortune of women. ${ }^{2 \text { " Women }}$ yearn for material things and want a beautiful life, but they relax their efforts and struggles. They simply want to rely on their physical strengths, such as looks and youthfulness, to gain the rights and wealth they need. In order to satisfy their material needs, they give up their responsibilities and morals and do not hesitate to destroy other people's marriages and families, leading to family fragmentation. All this significantly reduced the recognition of some women in society and became an obstacle to improving the social status of women.

1.2.3 Hedonism and money worship affect women's concept of learning

The distorted concept of marriage and love and the breeding of hedonism and money worship will also affect women's autonomy and enthusiasm in receiving education, and return to the past thinking. Learning well is not as good as marrying well, which will lead to fewer women taking the initiative to receive highlevel education. When the hardships of their own efforts are compared with the material enjoyment quickly obtained by other women through climbing and other means, once the gap is formed, it will affect more women's self-confidence and their determination to work hard.

In particular, when women reach a certain age due to nine years of compulsory education in China, plus three years of high school and four years of university studies, if women want to continue their further

\footnotetext{
1 安云凤 (2005). 中国传统婚姻与性道德论析. 道德与文明, 3, 49.

2 西蒙 (1986). 波伏娃. 第二性.湖南文艺出版社年版, 第58页.
} 
study, their time to enter society will be delayed. In the face of the emergence of the problem of "leftover women" in society, will women still have enough courage and determination to stick to it in the process of education? Will women's desire to strengthen their self-cultivation and improve their knowledge be affected by material factors in reality? Even if you have a firm self-awareness and principle of material desire, do you really care about becoming a "leftover woman" in the face of marital problems? Once the whole social atmosphere is formed, the improvement of women's social status has to be affected and restricted.

2 Own factors of women

2.1 There are large differences in women's independent awareness of the pursuit of happiness.

According to Marx's classical thought about class formation, class formation is divided into two classes: a class in itself and a class for itself ${ }^{1}$. When members of a class are in only one economic status and lead a similar lifestyle, but are not aware of their status and identity, this shows that they are only at the stage of a class in themselves; When they realized their own class interests through organized class struggle, they became a class for themselves.

It seems that women are neither in the class stage in themselves, nor in the class stage for themselves. Their own social status and happiness must be achieved through their own efforts. What should women pursue happiness? For example, Aristotle mentioned the external good causes of happy life: external good, body good and soul good ${ }^{2}$. Happy life should pursue the harmonious unity of material and spirit. After suppression and control for over two thousand years, women should experience the happiness of freedom and become a subject with an independent personality, freedom, self-confidence, respect, equality and care. A happy life depends on ourselves, from a change of consciousness to the courage to innovate and practice. However, perhaps it has been suppressed for too long and has been used to a life mode. Women's pursuit of happiness still stays on the perfection of marriage and family.

2.2 Influence of female physiological characteristics

Women's own physiological characteristics have obvious influences on their economic autonomy, political participation, social role-playing, marriage and love beliefs, and lifestyle.

2.2.1 Poor physical strength of female affects their employment.

Females are physiologically different from males, and they are born with a mission to reproduce. Especially in traditional thinking, women should take care of their husbands and educate children, and devote themselves to one [husband] for the rest of their lives.

The long-term loss of an independent personality made women psychologically rely on men. The physiological characteristics of women determine that women are inferior to men in physical strength. Faced with women looking for work in the labor market, employers often provide men with more opportunities, because women have not only menstruation, but also maternity leave, etc. Women's own physiological characteristics have a large impact on their employment. In the employment process, a large number of employers continue to face discrimination on the basis of gender. For women job seekers, most of them get rejected by companies on covert conditions, and some explicitly state that only men are required. In the process of rapid economic development, any enterprise seeks to make a profit, allocate resources, seek income and reduce costs. Thus, the physiological characteristics of women allow them to increase the burden on the enterprise and increase the cost of operating the enterprise. In addition, with the current distribution of the industrial structure in China, the service sector has not surpassed the primary and secondary industries, and manual labor in manufacturing is still very important. Consequently, women's own physiology will still affect their employment.

3. Women strive more for a stable life and lack creativity.

If women want to obtain more and better social materials, in addition to their own development, or through their own efforts of mental and physical work, the faster is through successful men. Finding a wealthy, powerful, or influential male partner directly can not only fulfill a woman's natural mission, but also enable women to quickly enter luxurious life. At least in the current situation, when social and economic development is of paramount importance, many women have such a mentality, which has led to the emergence of an increasing number of mistresses in society, and the behavior of keeping mistresses has been regarded as a "phenomenon of social moral corruption" from the beginning to now. Moreover, taking into account the development of human rights in the recently announced interpretation

\footnotetext{
1 李培林 (2005). 社会冲突与阶级意识 - - 当代中国社会矛盾研究. 社会, 25 (1), 7.

2 Валиахметов, И. 3. (2021). По страницам «Никомаховой этики» Аристотеля. In: Инновационныле процессы в науке и технике XXI века (pp. 7-11).
} 
of the New Law on Marriage, Section 25 states that "Children born out of wedlock enjoy the same rights as children born in wedlock and no one is allowed to harm or discriminate ${ }^{1}$ "... The announcement of the new rules not only strengthens the protection of children, but also removes anxiety for the mistress in one aspect. Numerous examples of successful mistresses, as a rule, induce women who do not have a full personality or do not have sufficient independence, to a greater extent to use the natural physiological factors of women in search of advantages for them, which does not contribute to an improvement in the general social status of women.

In the current social life of Chinese women, from some behaviors and choices, we can still find that they are deeply influenced by our traditional culture. For example, women are willing to return to their families as full-time wives to fully support their husbands' careers outside the home. Although the law stipulates that men and women are equal, women and men share the benefits of development, the scope of women's expression has also expanded, and girls receive the same education as boys, in terms of employment, family planning, child care, income control, educational investment, women's remarriage, calculation of wages, division of property, participation in politics, etc, Women are often vulnerable groups. Chinese women's life characteristics and Chinese people's attitude towards women are inevitably related to cultural traditions. Therefore, in the golden development of China's social transformation, the problem of women's low social status has not been solved in a real sense, and these problems bring more pressure to women in the development and transformation. The road of women's liberation is still long, and efforts should be continued to improve women's social status. Women should be independent individuals, realize their own life value and obtain their own happiness, rather than living in the ethical framework set by men. To promote the improvement of women's social status, we need the society to provide a loose living environment, the strong support and advocacy of the state, the help of enterprises and employers, and the self awakening of women's consciousness and the practical spirit of innovation.

Equality between men and women is relative. The improvement of women's social status does not mean the suppression of men's status, but the recognition of gender differences. Starting from the different physiological and psychological characteristics of women and men, both sexes develop together, more reasonable division of labor and cooperation, jointly promote social prosperity and share the achievements of advanced civilization brought by social development.

\section{References:}

1. National Bureau of Statistics (2021). Di er qi Zhong guo fu nv she hui di wei chou yang diao cha zhu yao shu ju bao gao [Main data report of the second sampling survey on the social status of Chinese women]. <http://www.stats.gov.cn/tjsj/tjgb/qttjgb/qgqttjgb/200203/t20020331_30606.html> (2021, November, 12). [in Chinese].

2. Huang, J. (2020). Wo guo nan nv liang xing de cha yi xing fen xi [Analysis on the differences between men and women in China]. Journal of Three Gorges University (Humanities and social sciences edition), S1, 10-14. [in Chinese].

3. Yang, Y. Y. (2018). Nv xing chuang ye yi xiang ji qi ying xiang yin su shi zheng yan jiu [Empirical Study on women's entrepreneurial intention and its influencing factors]: Master's thesis, Southwest Jiaotong University https://kns.cnki.net/KCMS/detail/detail.aspx?dbname=CMFD201802\&amp;filename=1018977032.nh> (2021, November, 12). [in Chinese].

4. Zhang, X., Ru, X. (2017). Zhong guo nv xing jin ji di wei de li shi yan jin ji qi dang dai qi shi [Historical evolution of women's economic status in China and Its Contemporary Enlightenment]. Fujian Forum (Humanities and social sciences edition), 09, 166-173. [in Chinese].

5. Li, G. M., Ouyang, Z. L. (2015). Dang dai Zhong guo nv xing dao de chuang kuang diao cha [Investigation on the moral status of contemporary Chinese women]. Ethical research, 04, 17-26. [in Chinese].

6. Zhang, J. P. (2010). Zhong guo nan zhu wai nv zhu nei de ke ban yin xiang tan jiu ji yu she hui xing bie shi jiao [An analysis of the stereotype of "men outside and women inside" in China - from a gender perspective]. Legal system and society, 17 (200), 0592-1009. [in Chinese].

7. Li, H. Y. (2008). Zhong guo nv zi jiao yu shi [History of Chinese women's education]. Library magazine, 27 (2), 89-91. [in Chinese].

8. Yang, W. Z. (2001). Lun san cong si de de lun li xue nei han ji qi li shi ju xian [On the ethical connotation and historical limitations of "three obediences and four virtues"]. Chinese culture, 2. [in Chinese].

9. Wei, M., Peng, D. Q. (2014). Qian xi zhu xi de san gang wu chang si xiang [An analysis of Zhu Xi's thought of "three cardinal principles and five standing orders"]. Legal system and society, 6. [in Chinese].

\footnotetext{
${ }^{1}$ The Central People's Government of the People's Republic of China (2021). Marriage Law of the People's Republic
} of China <http: //www.gov.cn/banshi/2005-05/25/content_847.htm> (2021, November, 12). 
10. Zhong, X. Y. (2014). Shi lun bian qin gong li zhu yi de dang dai zheng zhi lun li jia zhi [On the contemporary political and ethical value of Bentham utilitarianism]. Journal of the Party School of the CPC Sichuan Provincial Committee, 3, 49-52. [in Chinese].

11. An, Y. F. (2005). Zhong guo chuan tong hun yin yu xing dao de lun xi [Analysis of Chinese traditional marriage and sexual morality]. Morality and civilization, 3, 49. [in Chinese].

12. Simon, B. (1986). Second sex. Hunan: Literature and Art Publishing House.[ in English].

13. Li, P. L. (2005). She hui chong tu yu jie ji yi shi dang dai Zhong guo she hui maodun yan jiu [Social conflict and class consciousness - a study of social contradictions in contemporary China]. Society, 25 (1), 7. [in Chinese].

14. Valiakhmetov, I. Z. (2021). Po stranitsam «Nikomakhovoy etiki» Aristotelya [On the pages of "Nikomahova ethics" Aristotel]. In: Innovative processes in science and technology of the XXI century (pp. 7-11). [in Russian].

15. The Central People's Government of the People's Republic of China (2021). Marriage Law of the People's Republic of China <http: //www.gov.cn/banshi/2005-05/25/content_847.htm> (2021, November, 12). [in Chinese]. 